\title{
ANALISIS BAURAN PEMASARAN PADA PT. GLOBAL IMOO TELEKOMUNIKASI BENGKULU
}

\author{
Suwarni, Lusi Aprika, Nia Indriasari \\ Program Studi Manajemen Fakultas Ekonomi Universitas Dehasen Bengkulu \\ Suwarni.h13@gmail.com
}

\begin{abstract}
ABSTRAK
Suwarni, Lusi Aprika, Nia Indriasari; Tujuan dari penelitian ini adalah untuk mengetahui analisis campuran dari pemasaran ponsel jam Imoo di PT. Global Imoo Telekomunikasi Bengkulu. Sampel dalam penelitian ini adalah 49 konsumen yang melakukan pembelian jam tangan ponsel pintar di PT. Global Imoo Telekomunikasi Bengkulu. Pengambilan sampel dilakukan dengan teknik accidental sampling. Metode pengumpulan data dilakukan dengan menggunakan kuesioner dan metode analitik yang menggunakan analisis skala peringkat. Hasil penelitian ini menunjukkan bahwa nilai rata-rata tanggapan responden terhadap pemasaran di PT. Global Imoo Telekomunikasi Bengkulu adalah 1.003 dengan kriteria penilaian yang disepakati. Ini berarti bahwa responden memiliki penilaian yang disepakati atas pemasaran di PT. Global Imoo Telekomunikasi Bengkulu yang dipengaruhi oleh faktor produk, harga, promosi dan distribusi. Faktor tertinggi mempengaruhi bauran pemasaran di PT. Bengkulu Global Imoo Telekomunikasi adalah faktor produk dengan skor 1.067. Ini menggambarkan bahwa kualitas produk jam tangan ponsel pintar Imoo yang dijual oleh PT. Global Imoo Telekomunikasi Bengkulu memiliki kualitas yang baik, selain itu dapat digunakan untuk berkomunikasi. Selanjutnya, jam tangan ponsel pintar Imoo juga dapat digunakan untuk memantau keberadaan anak-anak. Faktor terendah adalah faktor harga dengan skor total 964 dengan kriteria penilaian yang disepakati. Ini menggambarkan bahwa faktor harga memiliki pengaruh yang rendah terhadap pemasaran di PT. Global Imoo Telekomunikasi Bengkulu karena harga yang ditawarkan oleh jam tangan ponsel pintar Imoo relatif tinggi, dibandingkan dengan banyak jam tangan ponsel pintar dari merek lain yang dijual dengan harga jauh lebih murah.
\end{abstract}

ABSTRACT

Suwarni, Lusi Aprika, Nia Indriasari; The purpose of this study was to figure out the mixed analysis of the marketing of Imoo watch phone at PT. Global Imoo Telekomunikasi Bengkulu. The sample in this study was 49 consumers who made the smart phone watches purchases at PT. Global Imoo Telekomunikasi Bengkulu. Sampling is done by accidental sampling technique. Data collection method was done using questionnaires and analytical methods which employed rating scale analysis. The results of this study indicate that the average value of respondents' responses to the marketing at PT. Global Imoo Telekomunikasi Bengkulu is 1,003 with the agreed assessment criteria. This means that the respondent has an agreed assessment of the marketing at PT. Global Imoo Telekomunikasi Bengkulu that is influenced by product, price, promotion and distribution factors. The highest factor influences the marketing mix at PT. Bengkulu Global Imoo Telekomunikasi is a product factor with a score of 1,067. This illustrates that the quality of Imoo smart phone watches products sold by PT. Global Imoo Telekomunikasi Bengkulu has good quality, besides it can be used to communicate. Furthermore, Imoo smart phone watches can also be used to monitor the whereabouts of children. The lowest factor is the price factor with a total score of 964 with agreed assessment criteria. This illustrates that the price factor has a low influence on the marketing at PT. Global Imoo Telekomunikasi Bengkulu because the price offered by Imoo smart phone watches is relatively high, compared to many smart phone watches from other brands that are sold at much cheaper prices

Keywords; Product, Price, Distribution, Promotion

\section{LATAR BELAKANG}

Pada saat sekarang ini dunia teknologi informasi terutama yang berkaitan dengan telekomunikasi sangat berkembang pesat. Ini ditandai dengan perkembangan internet, kemudian disusul dengan teknologi telepon seluler (ponsel) yang berkembang begitu cepat dan canggih sehingga setiap orang tertarik untuk memiliki. Perkembangan teknologi yang memunculkan revolusi baru seperti hubungan telepon dengan internet yang lebih baik, menyebabkan ponsel tidak hanya di gunakan sebagai alat komunikasi saja (telepon / sms), tetapi juga banyak digunakan sebagai media hiburan, pendidikan, pekerjaan.

Dengan adanya ponsel, mobilitas dan penggunaan waktu dalam melakukan aktivitas sehari-hari baik pekerjaan, pendidikan, bisnis oleh masyarakat menjadi lebih efektif dan efisien. Ponsel telah menjadi 
suatu kebutuhan yang sangat penting bagi manusia dalam kehidupan sehari-hari. Ditambah lagi, sekarang ini setiap orang tidak hanya memiliki suatu produk karena fungsinya saja, tetapi juga rasa bangga dan pengakuan yang didapatkan dari memiliki produk tersebut. Melihat kenyataan tingginya permintaan masyarakat akan ponsel, memberikan dampak yang signifikan terhadap aspek lain, seperti aspek bisnis.

Dinamika persaingan bisnis yang semakin sulit membawa penerapan pada upaya yang berkelanjutan agar produk dapat sampai ke konsumen di waktu yang tepat, tempat yang tepat, pada orang yang tepat, dan harga yang tepat. Sehingga bagian pemasaran memiliki posisi strategis dalam upaya membawa perusahaan ke arah yang lebih baik. Strategi pemasaran merupakan pegangan bagi perusahaan agar mempunyai keunggulan dalam persaingan pasar, sekaligus mencari kecocokan antara kemampuan internal perusahaan, dalam hal ini menjual produk ke konsumen dengan peluang ekstemal yang ada di pasar yaitu pembeli potensial yang menyukai produk yang dijual tersebut. Dengan demikian haruslah diketahui karakteristik pasar serta struktur pasar yang dihadapi.

Persaingan biasanya terjadi karena suatu perusahaan merasakan adanya tekanan dari perusahaan lain, atau melihat adanya peluang untuk bergerak dalam bidang usaha sejenis dengan perusahaan lain. Persaingan bisnis merupakan sebuah tantangan bagi pengusaha untuk tetap berada dalam pasar persaingan industri. Suatu perusahaan mengharapkan agar konsumennya puas sehingga dimasa mendatang ia mau datang dan melakukan pembelian kembali. Di dalam sistem bisnis kehilangan seorang pelanggan yang loyal adalah hal buruk. Loyalitas adalah komitmen yang dipegang kuat untuk membeli atau berlangganan lagi pada produk atau jasa tertentu di masa depan meskipun ada pengaruh situasi dan usaha pemasaran yang berpotensi menyebabkan perubahan perilaku. Dampaknya akan membuat kredibilitas dan reputasi usaha tersebut menurun. Perusahaan yang tidak dapat memenuhi selera konsumen praktis akan mengalami penurunan volume penjualan, jika perusahaan tersebut tahun demi tahun mengalami kemunduran produksi, sudah dipastikan perusahaan tersebut akan gulung tikar. Sehingga dengan semakin banyaknya pesaing dalam jenis industri yang sama, suatu perusahaan sebaiknya mempunyai spesifikasi produk yang unggul dibanding dengan perusahaan lain.

Dalam persaingan usaha, pelaku bisnis dituntut untuk memiliki kepekaan terhadap perubahanperubahan kondisi lingkungan (internal dan eksternal), sehingga dalam perencanaan dan penerapan strategi bisnis dalam hal pemasaran produk yang ditawarkan dapat lebih baik. Untuk mempertahankan kelangsungan usaha bisnis dalam persaingan, pelaku bisnis seringkali dihadapkan pada berbagai masalah seperti, bagaimana meningkatkan volume penjualan, semakin lengkapnya perilaku konsumen atas suatu produk, serta keadaan dan kondisi ekonomi yang tidak menentu. Kondisi lingkungan bisnis yang terus berkembang dengan tingkat persaingan tinggi, tidak saja menuntut perusahaan untuk sekedar mengatasi tantangan di masa sekarang, tetapi juga dituntut untuk dapat mengantisipasi segala dampak yang mungkin terjadi dari perubahan tersebut terhadap masa depan perusahaan.

Strategi bersaing adalah suatu bidang yang menjadi perhatian utama para manajer yang sangat tergantung pada pemahaman yang mendalam mengenai industri dan para pesaing. Tujuan strategi bersaing untuk suatu unit usaha adalah menemukan posisi dalam suatu industri dimana perusahaan dapat melindungi diri sendiri terhadap tekanan (daya) persaingan dengan sebaik-baiknya atau dapat mempengaruhi tekanan tersebut secara positif. Posisi aman dalam suatu persaingan dapat dicapai jika perusahaan mengembangkan dan menerapkan keunggulan bersaing secara berkelanjutan, untuk itu harus ada perencanaan yang efektif dan efisien dengan mengidentifikasi lingkungan (internal dan eksternal) yang ada disekitar perusahaan. Keunggulan bersaing itu sendiri merupakan keunggulan yang dimiliki oleh suatu perusahaan atas suatu produk jasa yang dimiliki dibandingkan pesaing sejenis. Keunggulan bersaing adalah jantung kinerja perusahaan untuk bersaing dalam pasar. Keungggulan bersaing pada dasarnya tumbuh dari nilai atau manfaat unggul dibanding pesaing lain yang dapat diciptakan perusahaan bagi para pembelinya.

Demi memenangkan persaingan, suatu usaha bisnis harus bisa memahami keinginan pasar yang ditunjang dengan suatu bauran pemasaran yang baik. Bauran pemasaran adalah kumpulan dari variabelvariabel pemasaran yang digunakan oleh perusahaan untuk mencapai tujuan pemasaran dalam pasar sasaran (Kotler, 2015 : 24). Konsep bauran pemasaran ini biasanya digunakan oleh perusahaan untuk menciptakan keputusan pembelian konsumen atas produk yang ditawarkan oleh perusahaan serta untuk mengukur sebesar apa pengaruh dari bauran pemasaran tersebut terhadap keputusan pembelian produk yang diambil oleh konsumen.

Berbeda dari zaman dahulu kala, sekarang ini jam tangan tidak lagi berfungsi sebagai penunjuk waktu saja. Berkat teknologi yang berkembang pesat, jam tangan sudah berevolusi menjadi smartwatch. Sama dengan smartphone alias ponsel pintar, jam tangan pintar juga bisa mendukung berbagai aktvitas dan membuat hidup jauh lebih mudah. Tidak hanya orang dewasa, anak-anak juga bisa menggunakan watch phone untuk mendukung aktivitas mereka. Salah satu watch phone yang baru beredar di pasaran adalah watch phone dengan merek Imoo yang dibuat khusus untuk anak-anak, watch 
phone keluaran Imoo sedang naik daun di pasaran. Dengan seri Watch Phone Y1 dan Watch Phone Z5, Imoo menawarkan jam tangan pintar berharga terjangkau. Dibanderol dengan harga yang terhitung murah mulai dari Rp. 999.000,-. Jam tangan pintar Imoo sangat banyak diminati oleh anak-anak karena dengan fiturnya yang canggih selain dapat digunakan sebagai jam tangan jam pintar Imoo juga bisa digunakan untuk berkomunikasi.

PT. Global Imoo Telekomunikasi merupakan perusahaan bergerak di bidang telekomunikasi dan edukasi elektronik. IMOO khusus mengembangkan produk jam tangan pintar untuk siswa siswi. Untuk memenuhi kebutuhan siswa siswi indonesia dalam perjalanan yang aman, pembelajaran komunikasi, dan tumbuh mandiri. Karena produknya dibilang masih baru dan belum banyak masyakarat yang mengenalnya makan PT. Global Imoo harus melakukan bauran pemasaran dengan gencar agar masyarakat mengenal produk yang mereka pasarkan. Bauran pemasaran yang dapat dilakukan oleh PT. Global Imoo Telekomunikasi Bengkulu adalah dengan memperhatikan empat bauran pemasaran yaitu produk, harga, promosi dan distribusi.

\section{Landasan Teori \\ Manajemen Pemasaran}

Menurut Gitosudarmo (2014 : 3) mengemukakan bahwa : Manajemen pemasaran adalah kegiatan pemasaran yang direncanakan dengan baik, diorganisasikan, dikoordinasikan serta diawasi akan membuahkan hasil yang memuaskan. Menurut Sunarto (2015 : 16) bahwa : "Manajemen pemasaran ialah sebagai analisis, perencanaan, implementasi, dan pengendalian dari program-program yang dirancang untuk menciptakan, membangun dan memelihara pertukaran yang menguntungkan dengan pembeli sasaran untuk mencapai tujuan perusahaan."

Umumnya orang beranggapan bahwa manajemen pemasaran berkaitan dengan upaya pencarian pelanggan dalam jumlah besar untuk menjual produk yang telah dihasilkan perusahaan. Tetapi pandangan ini terlalu sempit, karena biasanya suatu organisasi (perusahaan) akan menghadapi kondisi permintaan produk yang tingkatannya berbeda-beda. Pada suatu saat mungkin tidak ada permintaan terhadap produknya, mungkin permintaannya cukup, permintaannya tidak teratur, atau terlalu banyak permintaan, sehingga manajemen pemasaran harus mencari jalan untuk mengatasi keadaan permintaan yang berubah-ubah ini. Jadi, manajemen pemasaran tidak saja berkaitan dengan upaya mencari dan meningkatkan permintaan, tetapi juga mengelola permintaan pada saat tertentu.

Manajemen pemasaran dapat diterapkan di semua pasar. Misalkan sebuah perusahaan makanan. Direktur personalia menangani pasar tenaga kerja, direktur pembelian menangani pasar bahan baku. Mereka harus menetapkan tujuan dan mengembangkan strategi untuk mendapatkan hasil yang memuaskan dalam pasar-pasar tersebut. Namun biasanya pada eksekutif ini tidak disebut pemasar, ataupun telah dilatih dalam bidang pemasaran. Paling tidak mereka adalah pemasar "paruh-waktu". Sebaliknya manajemen pemasaran biasanya dihubungkan dengan tugas dan orang-orang yang menangani pasar pelanggan.

Manajemen pemasaran sebagai analisis, perencanaan implementasi, dan pengendalian dari program-program yang dirancang, untuk menciptakan, membangun dan memelihara pertukaran yang menguntungkan dengan pembeli sasaran untuk mencapai tujuan perusahaan. Manajemen pemasaran meliputi mengatur permintaan, yang selanjutnya mencakup mengatur hubungan dengan pelanggan. Definisi ini mempunyai beberapa pengertian penting mengingat :

1. Seluruh sistem dari kegiatan bisnis harus berorientasi ke pasar atau konsumen.

2. Keinginan konsumen harus diketahui dan dipuaskan secara efektif.

3. Pemasaran adalah proses bisnis yang dinamis karena merupakan sebuah proses integral yang menyeluruh dan bukan gabungan aneka fungsi dan pranata yang terurai.

4. Program pemasaran dimulai dengan sebutir gagasan produk dan tidak terhenti sampai keinginan konsumen benar-benar terpuaskan, mungkin beberapa waktu setelah penjualan dilakukan.

5. Untuk berhasil pemasaran harus memaksimalkan penjualan yang menghasilkan laba dalam jangka panjang.

Kegiatan pemasaran agar supaya dapat berjalan sesuai dengan tujuannya maka diperlukan adanya kegiatan manajemen atau manajerial. Kegiatan manajerial yang utama adalah : perencanaan, organisasi, koordinasi kerja, dan pengawasan. Adapun tugas manajer pemasaran adalah (Kotler, 2016:86):

1. Perencanaan terhadap kegiatan pemasaran

2. Menggiatkan pelaksanaan kegiatan pemasaran

3. Pengendalian kegiatan pemasaran

Secara ringkas tugas tersebut merupakan tugas-tugas manajerial yang paling awal dan yang paling menentukan terhadap keberhasilan program-program pemasaran adalah perencanaan. Sebagai manajer 
pemasaran haruslah mampu untuk menyusun rencana kegiatan pemasaran yang strategis, praktis atau operasional dan terprogram.

Dengan perencanaan yang baik maka akan diperoleh pedoman kerja bagi pelaksana pemasaran dalam mencapai sasarannya. Sasaran apakah yang akan diraih oleh bagian pemasaran, tidak lain adalah mengusahakan agar supaya konsumen selalu loyal untuk membeli produk yang dipasarkannya. Loyalitas konsumen terhadap perusahaan akan mengakibatkan terjadinya posisi persaingan yang unggul serta nama baik atau citra perusahaan.

Program pemasaran yang akan dilakukan tersebut merupakan kegiatan pemasaran yang meliputi empat macam hal atau masalah yang secara bersama-sama harus dipadukan menjadi satu kesatuan sehingga akan merupakan satu paket program yang terintegrasikan dengan baik. Integrasi atau perpaduan dari 4 macam hal itu akan merupakan kunci suksesnya kegiatan pemasaran. Perpaduan tidak boleh hanya bersifat penggabungan antara satu dengan yang lain secara terpisah-pisah, akan tetapi harus betul-betul menyatu dan saling topang-menopang antara masalah yang satu dengan yang lain. Dengan perpaduan yang baik maka akan terjadilah "sinergi" antara satu masalah dengan masalah yang lain sehingga menjadi saling menopang dan saling memperkuat serta saling membantu apabila terjadi goncangan di kemudian hari. Empat macam hal tersebut adalah : produk, harga, promosi, dan distribusi yang sering disebut bauran pemasaran.

Manajemen pemasaran berupaya mempengaruhi tingkat dan karakter permintaan dengan cara yang akan membantu pencapaian tujuan organisasi. Karena itu manajemen pemasaran sering disebut juga sebagai manajemen permintaan.

Menurut Fuad, dkk (2015 : 124) ada delapan permintaan yang berbeda-beda. Pada tiap keadaan, ada tugas tertentu yang harus dilakukan manajemen pemasaran. Kedelapan permintaan tersebut, yaitu :

"1. Permintaan negatif (negative demand)

2. Tidak ada permintaan (no demand)

3. Permintaan terpendam (latent demand)

4. Permintaan yang menurun (falling demand)

5. Permintaan yang tidak teratur (irregular demand)

6. Permintaan penuh (full demand)

7. Permintaan yang berlebihan (overfull demand)

8. Permintaan yang tidak sehat (unwholesome demand)."

Selanjutnya akan diuraikan satu persatu mengenai kedelapan manajemen permintaan di atas, sebagai berikut :

1. Permintaan negatif (negative demand)

Sebagian besar pasar tidak menyukai produk, bahkan berupaya untuk menghindarinya. Orang mempunyai permintaan negatif terhadap vaksinasi, tambal gigi, ataupun operasi usus buntu. Tugas pemasar adalah menganalisis mengapa pasar tidak menyukai produk, dan apakah suatu program pemasaran dapat mengubah kepercayaan dan sikap pasar melalui perancangan kembali produk, harga yang lebih rendah, dan promosi yang lebih positif.

2. Tidak ada permintaan (no demand)

Konsumen sasaran dapat saja tidak tertarik terhadap produk yang ditawarkan karena merasa tidak memiliki kepentingan terhadap manfaatnya. Misalnya petani yang tidak tertarik menggunakan teknologi baru di bidang pertanian atau mahasiswa yang tidak terlalu berminat mengikuti kursus bahasa asing. Tugas pemasar adalah menemukan cara untuk menghubungkan manfaat produk dengan kebutuhan minat dan pasar.

3. Permintaan terpendam (latent demand)

Banyak konsumen yang memiliki hasrat kuat terhadap sesuatu yang tidak dapat dipuaskan oleh produk atau jasa yang ada. Ada permintaan terpendam yang kuat akan rokok yang tidak membahayakan kesehatan, lingkungan yang lebih aman, dan mobil yang lebih hemat bahan bakar. Tugas pemasar adalah mengukur besarnya besar potensial ini dan mengembangkan barang serta jasa yang akan memuaskan permintaan terhadap produk tersebut.

4. Permintaan yang menurun (falling demand)

Setiap organisasi, cepat atau lambat, menghadapi menurunnya permintaan terhadap satu atau lebih produknya. Misalnya perusahaan Indofood melihat penurunan penjualan mie instannya, atau suatu Perguruan Tinggi mulai merasakan berkurangnya jumlah penerimaan mahasiswa baru. Pemasar baru menganalisis sebab-sebab penurunan pasar dan menentukan apakah permintaan dapat dirangsang kembali. Bila saja dengan mendapatkan pasar sasaran baru, dengan mengubah ciri produk, ataupun dengan mengembangkan komunikasi yang lebih efektif. Tugas pemasaran adalah meningkatkan kembali permintaan yang menurun melalui upaya pemasaran kembali produk bersangkutan dengan cara yang kreatif. 
5. Permintaan yang tidak teratur (irregular demand)

Banyak organisasi menghadapi permintaan yang berubah-ubah menurut musim, hari atau bahkan jam, sehingga penggunaan kapasitas pun menjadi berkurang, menganggur, atau bahkan berlebihan. Dalam bidang akuntan umum, misalnya banyak kendaraan yang menganggur pada jam-jam sepi, tetapi terjadi kekurangan kendaraan pada jam-jam sibuk. Taman-taman hiburan atau kebun binatang kekurangan pengunjung pada hari-hari biasa, tetapi padat pada akhir pekan atau hari-hari libur. Tugas pemasaran adalah menemukan cara untuk mengubah pola waktu permintaan melalui cara penentuan harga yang lebih fleksibel, promosi, dan rangsangan lainnya.

6. Permintaan penuh (full demand)

Suatu organisasi menghadapi permintaan penuh apabila organisasi itu puas terhadap volume usaha atau hasil yang telah dicapainya, terutama menyangkut jumlah permintaan yang diharapkannya. Tugas pemasaran adalah mempertahankan tingkat permintaan ini di tengah perubahan selera konsumen serta meningkatnya persaingan. Organisasi harus mempertahankan atau meningkatkan mutu produknya dan terus-menerus mengukur kepuasan konsumen untuk memperoleh kepastian bahwa semua telah berjalan dengan baik.

7. Permintaan yang berlebihan (overfull demand)

Beberapa organisasi menghadapi tingkat permintaan yang lebih tinggi daripada yang dapat atau ingin dilayaninya, misalnya Kebun Binatang Ragunan menghadapi pengunjung yang penuh sesak saat hari raya. Tugas pemasaran adalah melakukan demarketing, yaitu menemukan cara untuk mengurangi permintaan sementara maupun permanen, seperti dengan menaikkan harga, mengurangi promosi, ataupun aktivitas pelayanan. Tentu saja aktivitas ini dilakukan tidak untuk menghilangkan permintaan, tetapi hanya mengurangi tingkatannya.

8. Permintaan yang tidak sehat (unwholesome demand)

Produk-produk yang tidak sehat akan memunculkan upaya yang terorganisasi untuk mengurangi ataupun mencegah penggunaannya, seperti publikasi yang dilakukan untuk mengurangi bahkan menolak penjualan rokok, obat bius, ecstasy, ataupun senjata api dan pornografi. Tugas pemasar adalah mengajak orang-orang yang menggemari produk-produk ini untuk mengurangi atau meninggalkannya, dengan peningkatan harga, memberikan ancaman bagi yang menggunakan, maupun Marketing Mix (Bauran Pemasaran)

Hurriyati (2017: 42) bahwa Bauran pemasaran (marketing mix) merupakan unsur-unsur internal penting yang membentuk program pemasaran sebuah organisasi.

Lain halnya menurut Gitosudarmo (2014: 182) mendefinisikan bauran pemasaran sebagai alat bagi pengusaha untuk mempengaruhi konsumen agar konsumennya dapat menjadi kenal kemudian menyenangi dan kemudian melakukan transaksi pembelian serta akhirnya konsumen itu menjadi puas.

Menurut Kotler (2016:88) strategi pemasaran adalah himpunan asas yang secara tepat, konsisten, dan loyal dilaksanakan oleh perusahaan guna mencapai sasaran pasar yang dituju (target market) dalam jangka panjang. Dalam strategi pemasaran ini, terdapat strategi acuan/bauran pemasaran (marketing $m i x$ ), yang menetapkan komposisi terbaik dari keempat komponen atau variabel pemasaran, untuk dapat mencapai sasaran pasar yang dituju sekaligus mencapai tujuan dan sasaran perusahaan.

Tujuan perusahaan untuk menciptakan produk yang sesuai dengan kebutuhan konsumen bukan semata-mata tanggung jawab manajemen pemasaran saja, tetapi tanggung jawab semua orang yang terlibat dalam penciptaan produk, mulai dari bagian produksi, personalia, keuangan, hingga bagian pemasaran. Semua bagian atau departemen dalam perusahaan tersebut harus bekerja sama untuk memikirkan, merencanakan, menciptakan produk dan mendistribusikan hingga sampai ke tangan konsumen.

Tugas dan tanggung jawab manajemen pemasaran dalam memikirkan usaha-usaha pemasaran yang merupakan sumbangan pencapaian tujuan perusahaan. Secara ringkas tujuan-tujuan manajer perusahaan adalah merencanakan kegiatan, menggiatkan dan mengendalikan kegiatan pemasaran. Tugas-tugas ini sebenarnya merupakan tugas-tugas manajerial yang meliputi perencanaan, pelaksanaan, dan pengawasan terhadap kegiatan pemasaran.

Kombinasi dari strategi produk, harga, promosi dan distribusi dalam mencapai tujuan pemasaran dinamakan "marketing mix" atau bauran pemasaran. Marketing mix juga sering disebut 4P (Product, Price, Promotion, and Placement) dalam pemasaran yang merupakan alat yang dapat digunakan produsen untuk mempengaruhi konsumen.

Di samping itu pengusaha dapat pula mencantumkan harga yang rendah serta pemberian discount atau potongan harga, mencantumkan harga obral serta harga cuci gudang dan sebagainya. Dengan cara penetapan harga semacam ini akan dapat menarik perhatian serta mendorong konsumen untuk segera melakukan transaksi pembelian agar tidak terlewatkan kesempatan yang terbatas waktunya bagi berlakunya harga obral tersebut. 
Marketing mix terdiri dari himpunan variabel yang dapat dikendalikan dan digunakan oleh perusahaan untuk mempengaruhi tanggapan konsumen dalam pasar sasarannya.Variabel atau kegiatan tersebut perlu dikombinasikan dan dikoordinasikan oleh perusahaan seefektif mungkin dalam melakukan tugas atau kegiatan pemasarannya. Dengan demikian, perusahaan tidak hanya sekadar memiliki kombinasi kegiatan yang terbaik saja, akan tetapi dapat mengkoordinasikan barbagai variabel marketing mix tersebut untuk melaksanakan program pemasaran secara efektif.

Gitosudarmo (2014 : 182) bahwa unsur-unsur bauran pemasaran (marketing mix), yaitu :

1. Produk (product)

Produk adalah barang atau jasa yang bisa ditawarkan di pasar untuk mendapatkan perhatian, permintaan, pemakaian, atau konsumsi yang dapat memenuhi keinginan atau kebutuhan. Pembeli akan membeli kalau merasa cocok. Karena itu, produk harus disesuaikan dengan keinginan ataupun kebutuhan pembeli agar pemasaran produk berhasil.

2. Harga (Price)

Pengusaha perlu memikirkan tentang penetapan harga jual produknya secara tepat karena harga yang tidak tepat akan berakibat tidak menarik para pembeli untuk membeli barang tersebut. Penetapan harga jual barang yang tepat tidak selalu berarti bahwa harga haruslah ditetapkan rendah atau serendah mungkin. Sering di jumpai bahwa apabila harga barang tertentu itu rendah maka banyak konsumen justru tidak senang karena dengan harga yang murah itu maka semua orang dapat memakai barang tersebut.

Harga merupakan satu-satunya unsur marketing mix yang menghasilkan penerimaan penjualan, sedangkan unsur lainnya hanya unsur biaya saja. Walaupun penetapan harga merupakan persoalan penting, masih banyak perusahaan yang kurang sempurna dalam menangani permasalahan penetapan harga tersebut. Karena menghasilkan penerimaan penjualan, maka harga mempengaruhi tingkat penjualan, tingkat keuntungan, serta share pasar yang dapat dicapai oleh perusahaan.

3. Distribusi (Place)

Pengusaha haruslah menyebarkan barang-barangnya ke tempat konsumen itu berada. Hal ini merupakan tugas untuk mendistribusikan barangnya kepada konsumen. Untuk keperluan tersebut pengusaha dapat menggunakan berbagai bentuk saluran distribusi yang mungkin dilakukannya.

4. Promosi (Promotion)

Promosi adalah merupakan kegiatan yang ditujukan untuk mempengaruhi konsumen agar mereka dapat menjadi kenal akan produk yang ditawarkan oleh perusahaan kepada mereka dan kemudian mereka menjadi senang lalu membeli produk tersebut.

\section{Produk}

Menurut Kotler (2014:78) mendefinisikan produk sebagai segala sesuatu yang bisa ditawarkan untuk memenuhi kebutuhan dan keinginan. Produk merupakan pandangan pertama bagi konsumen dalam membeli karena dapat dipastikan bahwa konsumen akan menyukai suatu barang yang menarik dan bermanfaat.

Menurut Handoko (2014):142, "Kualitas adalah suatu kondisi dari sebuah barang berdasarkan pada penilaian atas kesesuaiannya dengan standar ukur yang telah ditetapkan." Berdasarkan pendapat ini diketahui bahwa kualitas barang ditentukan oleh tolak ukur penilaian. Semakin sesuai dengan standar yang ditetapkan dinilai semakin berkualitas.

Menurut Tjiptono (2014:77) kualitas produk adalah kualitas meliputi usaha memenuhi atau melebihi harapan pelanggan; kualitas mencakup produk, jasa, manusia, proses, dan lingkungan; kualitas merupakan kondisi yang selalu berubah (misalnya apa yang dianggap merupakan kualitas saat ini mungkin dianggap kurang berkualitas pada masa mendatang).

Produk menjadi instrumen penting untuk mencapai kesuksesan dan kemakmuran pada perusahaan modern. Perkembangan teknologi, peningkatan persaingan global, serta kebutuhan dan keinginan pasar mengharuskan perusahaan melakukan pengembangan produk yang terus menerus. Hanya ada dua pilihan yaitu sukses dalam pengembangan produk

Menurut Kotler dan Amstrong (2014:152) kualitas produk menggambarkan sejauh mana kemampuan produk tersebut dalam memenuhi kebutuhan konsumen. Definisi dari kualitas produk mencerminkan kemampuan produk untuk menjalankan tugasnya yang mencakup daya tahan, kehandalan atau kemajuan, kekuatan, kemudahan dalam pengemasan dan reparasi produk dan ciri- ciri lainnya

Menurut Tjiptono (2014:85) mengungkapkan ada lima dimensi kualitas produk, yaitu

a) Kinerja (performance) 
Kinerja merupakan karakteristik atau fungsi utama suatu produk. Ini manfaat atau khasiat utama produk yang kita beli. Biasanya ini menjadi pertimbangan pertama kita dalam membeli suatu produk.

b) Fitur Produk

Dimensi fitur merupakan karakteristik atau cirri-ciri tambahan yang melengkapi manfaat dasar suatu produk. Fitur bersifat pilihan atau option bagi konsumen. Kalau manfaat utama sudah standar, fitur sering kali ditambahkan. Idenya, fitur bisa meningkatkan kualitas produk kalau pesaing tidak memiliki.

c) Keandalan (reliability)

Dimensi keandalan adalah peluang suatu produk bebas dari kegagalan saat menjalankan fungsinya.

d) Kesesuaian dengan spesifikasi (conformance to specification) Conformance adalah kesesuaian kinerja produk dengan standar yang dinyatakan suatu produk. Ini semacam "janji” yang harus dipenuhi oleh produk. Produk yang memiliki kualitas dari dimensi ini berarti sesuai dengan standarnya.

e) Daya Tahan (durability)

Daya tahan menunjukan usia produk, yaitu jumlah pemakian suatu produk sebelum produk itu digantikan atau rusak. Semakin lama daya tahannya tentu semakin awet, produk yang awet akan dipersepsikan lebih berkualitas dibanding produk yang cepat habis atau cepat diganti

\section{Harga}

Menurut Simamora (2013:30) harga adalah sejumlah nilai yang dipertukarkan untuk memperoleh suatu produk. Sedangkan menurut Suwarman (2014:303) harga adalah atribut produk atau jasa yang paling sering digunakan oleh sebagian besar konsumen untuk mengevaluasi produk.

Lebih lanjut Tjiptono (2014: 34) mengatakan bahwa, harga memiliki dua peranan utama dalam mempengaruhi keputusan beli, yaitu :

1. Peranan alokasi dari harga, yaitu fungsi harga dalam membantu parapembeli untuk memutuskan cara memperoleh manfaat atau utilitastertinggi yang diharapkan berdasarkan daya belinya. Dengan demikian, adanya harga dapat membantu para pembeli untuk memutuskan cara mengalokasikan daya belinya pada berbagai jenis barang dan jasa. Pembeli membandingkan harga dari beberapa alternatif yang tersedia, kemudian memutuskan alokasi dana yang dikehendaki.

2. Peranan informasi dari harga, yaitu fungsi harga dalam mendidik konsumen mengenai faktor-faktor produk, seperti kualitas. Hal ini terutama bermanfaat dalam situasi dimana pembeli mengalami kesulitan untuk menilai faktor produk atau manfaatnya secara obyektif.

Dari beberpa teori dan penjelasan diatas, maka dapatlah disebutkan indikator harga, antara lain terdiri dari (Stanton, 2015:308):

1. Keterjangkauan harga

Keterjangkauan harga adalah harga sesungguhnya dari suatu produk yang tertulis di suatu produk, yang harus dibayarkan oleh pelanggan. Maksudnya adalah pelanggan cenderung melihat harga akhir dan memutuskan apakah akan menerima nilai yang baik seperti yang diharapkan

2. Kesesuaian harga dengan kualitas produk Untuk penetapan harga suatu produk, kualitas produk harus menjadi perhatian karena harga yang ditetapkan harus sesuai dengan kualitas produk yang ada

3. Kesesuaian harga dengan manfaat pelanggan mengevaluasi perbedaan diantara semua manfaat dan semua biaya pemasaran yang relatif sama dengan penawaran pesaing.

\section{Promosi}

Menurut Sutisna (2014:267), menyatakan bahwa promosi adalah usaha untuk menyampaikan pesan kepada publik terutama konsumen sasaran mengenai keberadaan produk di pasar. Menurut Alma (2012:135), mengemukakan bahwa promosi adalah sejenis komunikasi yang memberi penjelasan yang meyakinkan calon konsumen tentang barang dan jasa.

Sedangkan menurut Saladin (2014:171) menyatakana bahwa promosi adalah salah satu unsur dalam bauran pemasaran perusahaan yang didayagunakan untuk memberitahukan, membujuk, dan mengingatkan tentang produk perusahaan.

Dari definisi para ahli diatas, maka dapat diambil kesimpulan bahwa promosi merupakan alat komunikasi dan penyampaian pesan yang dilakukan baik oleh perusahaan maupun perantara dengan 
tujuan memberikan informasi mengenai produk, harga, dan tempat. Informasi itu bersifat memberitahukan, membujuk dan mengingatkan kembali kepada konsumen, atau para perantara.

Secara singkat promosi ini berkaitan dengan upaya untuk mengarahkan seseorang untuk dapat mengenal produk perusahaan, lalu memahaminya, berubah sikap, menyukai, yakin, , kemudian akhirnya membeli dan akan selalu ingat akan produk tersebut. Dalam promosi ini, juga terdapat kombinasi dari beberapa unsur yang dapat mendukung jalannya sebuah promosi tersebut yang biasa disebut dengan bauran promosi.

Menurut Kotler dan Armstrong (2014:213), menyatakan bahwa bauran promosi terdiri dari:

a. Periklanan (Advertising)

Iklan adalah sarana promosi yang digunakan oleh perusahaan guna menginformasikan segala sesuatu produk yang dihasilkan oleh perusahaan. Informasi yang diberikan adalah manfaat produk, harga produk serta keuntungan produk dibandingkan pesaing. Tujuan promosi lewat iklan adalah berusaha untuk menarik dan mempengaruhi calon pelanggan nya.

Penggunaan promosi lewat iklan dapat dilakukan dengan berbagai media, seperti lewat:

a) Pemasangan billboard (papan nama) di jalan-jalan strategis;

b) Pencetakan brosur baik disebarkan di setiap cabang atau pusat- pusat perbelanjaan;

c) Pemasangan spanduk di lokasi tertentu yang strategis;

d) Melalui koran;

e) Melalui majalah;

f) Melalui televisi;

g) Melalui radio;

h) Dan menggunakan media lainnya

b. Promosi Penjualan (Sales Promotion)

Disamping promosi lewat iklan, promosi lainnya bisa dilakukan melalui promosi penjualan atau sales promotion. Tujuan promosi penjualan adalah untuk meningkatkan penjualan atau untuk meningkatkan jumlah pelanggan . Promosi penjualan dilakukan untuk menarik pelanggan untuk segera membeli setiap produk atau jasa yang ditawarkan. Tentu saja agar pelanggan tertarik untuk membeli, maka perlu dibuatkan promosi penjualan yang semenarik mungkin.

Promosi penjualan dapat dilakukan melalui pemberian diskon, kontes, kupon, atau sampel produk. Dengan menggunakan alat tersebut akan memberikan 3 manfaat bagi promosi penjualan, yaitu :

a) Komunikasi, yaitu memberikan informasi yang dapat menarik perhatian pelanggan untuk membeli.

b) Insentif, yaitu memberikan dorongan dan semangat kepada pelanggan untuk segera membeli produk yang ditawarkan.

c) Invitasi, mengharapkan pelanggan segera merealisasikan pembelian.

Sama seperti halnya dengan iklan, promosi penjualan juga memilki program tersendiri. Dalam praktiknya program promosi penjualan memiliki tiga macam cara :

1) Promosi konsumen, seperti penggunaan kupon, sampel produk, hadiah, atau bentuk undian.

2) Promosi dagang, yaitu berupa bantuan peralatan atau insentif.

3) Promosi wiraniaga, melalui kontes penjualan.

c. Publisitas (Publicity)

Promosi yang ketiga adalah publisitas. Publisitas merupakan kegiatan promosi untuk memancing pelanggan melalui kegiatan seperti pamera, bakti sosial, serta kegiatan lainnya. Kegiatan publisitas dapat meningkatkan pamor perusahaan di mata pelanggannya. Oleh karena itu publisitas perlu diperbanyak lagi. Tujuannya adalah agar pelanggan mengenal perusahaan lebih dekat. Dengan ikut kegiatan tersebut, pelanggan akan selalu mengingat perusahaan tersebut dan diharapkan akan menarik pelanggan . Kegiatan publisitas dapat dilakukan melalui:

1) Ikut pameran.

2) Ikut kegiatan amal.

3) Ikut bakti sosial.

4) Sponsorship kegiatan.

d. Penjualan Pribadi (Personel Selling)

Kegiatan promosi yang keempat adalah penjualan pribadi atau personal selling. Dalam dunia perperusahaan an penjualan pribadi secara umum dilakukan oleh seluruh pegawai perusahaan , mulai dari cleaning service, satpam, sampai pejabat perusahaan . Personal selling juga dilakukan melalui merekrut tenaga-tenaga salesmen dan salesgirl untuk melakukan penjualan door to door. 


\section{Distribusi}

Banyak orang kadang bingung apakah ada kesamaan antara saluran distribusi dengan saluran pemasaran. Maka disini penulis akan mencoba mengungkapkan dengan sebuah pendapat dari Saladin (2016:107) menyatakan bahwa :"Saluran pemasaran atau saluran distribusi terdiri dari seperangkat lembaga yang melakukan semua kegiatan atau fungsi yang digunakan untuk menyalurkan produk dan status kepemilikannya dari produsen ke konsumen".

Dari pendapat di atas dapat penulis simpulkan bahwa saluran pemasaran dan saluran distribusi mempunyai kesamaan arti yaitu penyaluran produk dari produsen ke konsumen.

Untuk lebih jelas dan untuk lebih mengetahui atau memahami apa yang dimaksud dengan saluran distribusi, maka perlu adanya beberapa pendapat mengenai definisi saluran distribusi yang dikemukakan oleh ahli marketing.

Menurut Saladin (2016:153) mengemukakan tentang definisi saluran distribusi sebagai berikut :"Marketing channel can be viewed as sets of interdependent organization involued in the process of making a product or servise available for use or consumption".

Sedangkan menurut Kotler (2014: 682), sistem distribusi adalah sumber daya eksternal yang utama. Biasanya perlu bertahun- tahun untuk membangunnya, dan tidak dapat dirubah dengan mudah. Sistem ini sama pentingnya dengan sumber daya internal utama lainnya seperti produksi, riset, rekayasa, dan personil penjualan serta fasilitas lapangan. Sistem ini menggambarkan komitmen signifikan perusahaan terhadap sejumlah besar perusahaan independent yang bisnisnya adalah distribusi dan tehadap pasar tertentu yang mereka layani. Sistem distribusi juga menggambarkan komitmen terhadap seperangkat kebijakan dan praktek yang merupakan bahan dasar untuk disusun menjadi suatu hubungan jangka panjang yang luas.

Dari definisi di atas dapat kita simpulkan bahwa saluran distribusi selalu terdiri dari produsen dan konsumen akhir. Termasuk di dalamnya perantara yang terlibat dalam pemindahan kepemilikan barang. Para perantara juga merupakan bagian dari saluran distribusi

Menurut Saladin (2016:157) bahwa faktor - faktor yang mempengaruhi saluran distribusi adalah sebagai berikut :

1. Karakteristik produk

Produk yang tidak tahan lama haruslah memakai pemasaran langsung karena bahaya yang timbul karena penundaaan penanganan yang berulang - ulang. Produk yang berukuran besar seperti materi - materi gedung atau minuman ringan butuh saluran yang dapat meminimalisasikan jarak pengapalan dan jumlah penanganan ketika berpindah dari produsen ke konsumen. Produk yang tidak terstandarisasi seperti mesin yang khusus dibuat dan kertas - kertas cetakan bisnis yang khusus secara langsung dijual oleh tenaga penjual perusahaan. Produk - produk yang memerlukan instalansi dan pelayanan serta perawatan biasanya dijual dan ditangani oleh perusahaan itu sendiri atau oleh jaringan penyalur yang eksklusif. Produk - produk yang mempunyai nilai unit yang tinggi lebih sering dijual melalui organisasi penjualan perusahaan daripada melalui perantara.

2. Karakteristik perantara

Perancangan saluran menunjukkan kekuatan dan kelemahan berbagai jenis perantara yang berbeda. Ketika menangani tugas tertentu misalnya, representative produsen dapat berhubungan dengan pelanggan dengan biaya per pelanggan lebih rendah karena total biaya dibagi kepada beberapa klien. Tetapi usaha - usaha penjualan akan kurang giat jika tenaga penjualan itu melakukan penjualan sendiri. Pada umumnya perantara pemasaran berbeda dalam sikap penanganan promosi, negoisasi, penyimpanan, kontak, dan kredit.

3. Karakteristik pesaing

Perancangan saluran pemasaran dipengaruhi oleh saluran pemasaran pesaing. Produsen dapat bersaing dengan toko - toko yang sama yang menjual produk - produk pesaing. Maka produsen menginginkan produk mereka dipamerkan bertetangga dengan produk pesaing. Pada industri industri lainnya, produsen dapat menginginkan menghindari saluran - saluran pemasaran yang digunakan oleh pesaing.

4. Karakteristik perusahaan

Karakteristik perusahaan memcerminkan peranan penting dalam perancangan saluran. Saluran pemasaran perusahaan akan dipengaruhi oleh tujuan - tujuan, sumber - sumber, bauran produk, dan strategi pemasaran.

5. Karakteristik lingkungan Apabila kondisi ekonomi lesu, produsen akan memindahkan barang - barang ke pasaran dengan cara yang ekonomis. Ini berarti menggunakan saluran distribusi yang lebih pendek dan melepaskan pelayanan yang tidak perlu, menambah harga akhir dari barang - barang itu. Regulasi dan 
pembatasan hukum juga mempengaruhi saluran pemasaran. Hukum menganggap negatif terhadap pengaturan saluran pemasaran yang cenderung menciptakan suatu monopoli.

\section{Kerangka Analisis}

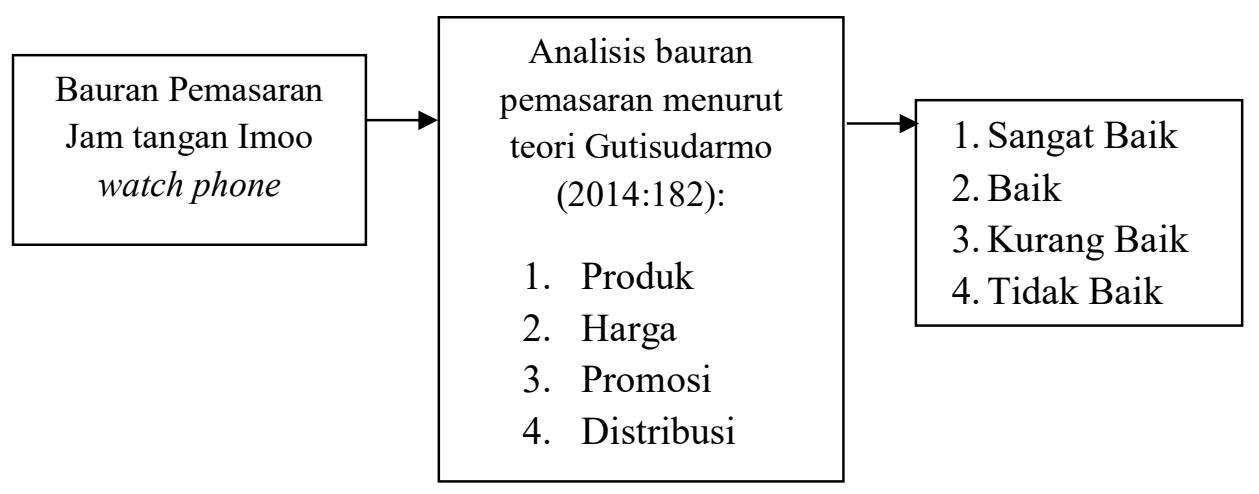

Gambar 1. Kerangka Analisis

\section{Jenis Penelitian}

Jenis penelitian ini merupakan suatu penelitian yang bersifat deskriptif kuantitatif, Sugiyono (2013: 147). Metode deskriptif kuantitatif adalah suatu metode penelitian dalam penelitian yang meneliti status kelompok manusia, suatu objek, suatu sistem pemikiran atau pun kelas manusia masa sekarang. Dalam penelitian ini dikemukakan adalah faktor yang mempengaruhi bauran pemasaran jam tangan pintar Imoo pada PT. Global Imoo Telekomunikasi Bengkulu yang dilihat dari produk, harga, promosi dan distribusi dan dianalisis untuk mengetahui faktor yang paling dominan mempengaruhi bauran pemasaran.

\section{Metode Analisis}

Metode analisis yang digunakan adalah rating scale, analisis rating scale yaitu pengolahan data mentah berupa angka kemudian ditafsirkan dalam pengertian kualitatif, jadi pengukuran dengan menggunakan reating scale ini dalam pengolahannya mengubah data yang bersifat kuantitatif menjadi kualitatif, kelebihan dari reating scale adalah lebih fleksibel (Sugiyono, 2014:141).

Sebelum dianalisis perolehan hasil angkat ditabulisasikan untuk memudahkan perhitungan. Perolahan skor hasil pengumpulan data dijumlahkan dari nomor satu sampai nomor terakhir. Sementara itu terdapat skor kriterium, yaitu skor tertinggi dikalikan dengan jumlah butir pertanyaan dan jumlah responden kemudian skor terendah dikalikan dengan jumlah butir pertanyaan dan jumlah responden. Skala interprestasi dibuat dengan mengurangi skor kriterium tertinggi dengan terendah dibagi jumlah kelas. Hasil secara kontinum adalah sebagai berikut :
Skor kriterium tertinggi
: $5 \times 5 \times 49$
$: 1 \times 5 \times 49$

$$
=1.225
$$$$
=245
$$

Selanjutnya mencari interval kelas dengan menggunakan rumus (Sugiyono, 2013:99) :

Interval kelas $\quad=\quad$ Skor kriterium tertinggi - Skor kriterium terendah Jumlah Kelas

$$
\begin{aligned}
& =\frac{1.225-245}{5}=\underline{980} \\
& =196
\end{aligned}
$$

Nilai interval setiap kelas adalah sebesar 196 maka dapat disusun kriteria setiap jawaban responden sebagai berikut :

$$
\begin{array}{lll}
\text { 1. } & 245-441 & \text { = Sangat Tidak Setuju } \\
\text { 2. } & 442-637 & \text { = Tidak Setuju } \\
\text { 3. } & 638-833 & \text { = Ragu-Ragu } \\
\text { 4. } & 834-1.029 & \text { = Setuju } \\
\text { 5. } & 1.030-1.225 & \text { = Sangat Setuju }
\end{array}
$$

Secara kontinum seperti pada gambar 2 berikut: 
Gambar 2. Interval Jawaban Responden

\begin{tabular}{|l|l|l|l|l|l|l} 
STS & \multicolumn{2}{|c|}{ TS RG } & & \\
& & & & & & \\
& 245 & 441 & 637 & 833 & 1.029 &
\end{tabular}

Sumber: Sugiyono (2013:99).

\section{HASIL PENELITIAN DAN PEMBAHASAN}

Dari hasil penelitian terhadap analisis bauran pemasaran pada PT. Global Imoo Telekomunikasi Bengkulu, adapun hasil penelitian terhadap faktor produk, harga , promosi dan distribusi seperti pada tabel berikut :

Tabel 1. Tanggapan Responden terhadap faktor-faktor yang mempengaruhi bauran pemasaran

\begin{tabular}{|c|c|c|c|}
\hline \multirow[t]{2}{*}{$\begin{array}{l}\text { Analisis bauran pemasaran } \\
\text { menurut teori } \\
\text { Gutisudarmo }(2014: 182) \text { : }\end{array}$} & \multicolumn{3}{|c|}{$\begin{array}{c}\text { Hasil Penelitian } \\
\text { Bauran pemasaran pada PT. Global Imoo Telekomunikasi } \\
\text { Bengkulu Berdasarkan Nomor Perangkingkingan }\end{array}$} \\
\hline & Nomor Rangking & Skor & Kriteria \\
\hline 1. Produk & 1. Produk & 1.067 & Sangat Setuju \\
\hline 2. Harga & 2. Promosi & 1.003 & Setuju \\
\hline 3. Promosi & 3. Distribusi & 979 & Setuju \\
\hline \multirow[t]{2}{*}{ 4. Distribusi } & 4. Harga & 964 & Setuju \\
\hline & Rata-Rata & 1.003 & Setuju \\
\hline
\end{tabular}

Sumber : Hasil Penelitian Data Diolah, 2019

Berdasarkan hasil penelitian dapat dilihat bahwa adanya perbedaan antara bauran pemasaran menurut Gutisudarmo (2014:182) dengan faktor yang mempengarui bauran pemasaran menurut PT. Global Imoo Telekomunikasi Bengkulu. Hasil penelitian menunjukan faktor yang paling dominan mempengaruhi bauran pemasaran adalah faktor produk.

Rata-rata dari tanggapan responden terhadap bauran pemasaran pada PT. Global Imoo Telekomunikasi Bengkulu adalah sebesar 1.003 dengan kriteria penilaian setuju. Artinya responden memiliki penilaian setuju terhadap bauran pemasaran pada PT. Global Imoo Telekomunikasi Bengkulu dipengaruhi oleh faktor produk, harga, promosi dan distribusi .

Faktor yang tertinggi mempengaruhi bauran pemasaran pada PT. Global Imoo Telekomunikasi Bengkulu adalah faktor produk dengan skor sebesar 1.067. Hal ini menggambarkan bahwa kualitas produk jam tangan pintar Imoo yang dijual oleh PT. Global Imoo Telekomunikasi memiliki kualitas yang bagus. Hal ini terlihat dari jam tangan pintar Imoo Watch phone tampil dengan desain menarik berkat warna yang cukup mencolok. Jam tangan pintar besutan Imoo ini nyaman dipakai karena memiliki bodi ramping dengan ketebalan 12,98 $\mathrm{mm}$ dan dipadukan dengan strap berbahan Dow Corning TPSV yang lentur, nyaman, dan tembus udara.

Imoo Watch phone tak hanya tampil dengan desain menarik, tetapi juga tangguh dengan kemampuan tahan air. Jam tangan pintar ini telah dirancang dengan komponen khusus guna memenuhi standar IPX8, sehingga tidak masalah digunakan saat berenang, kehujanan atau terkena cipratan air. Keunggulan lain yang ditawarkan oleh Imoo Watch phone adalah tidak mengganggu anak saat sekolah dengan dukungan Class Mode dan School Safe Route. Class Mode akan membatasi fungsi jam tangan saat berada dalam kelas agar tidak mengganggu konsentrasi belajar. Sementara fitur School Safe Route berfungsi memantau anak agar orangtua lebih tenang. Aplikasi ini akan secara otomatis mengirim pesan ke orangtua ketika anak telah sampai rumah, anak keluar dari sekolah, berhenti di jalan, dan ketika anak sudah sampai sekolah. Imoo Watch phone juga dilengkapi fitur untuk mendeteksi lokasi anak melalui smartphone. Berkat fitur ini, orangtua tak perlu khawatir keberadaan anak karena dapat dilacak lokasinya. Imoo Watch phone mendukung fitur GPS, Base Station, sensor percepatan, dan A-GPS. Imoo Watch phone juga didukung kapasitas baterai cukup besar, yakni 680mAh. Orangtua tak perlu khawatir soal keamanan jam tangan pintar andalan Imoo ini karena diklaim telah dilengkapi dengan chip built-in untuk perlindungan keamanan saat mengisi daya.

Faktor terendah adalah pada faktor harga dengan total skor sebesar 964 dengan kriteria penilaian setuju. Hal ini menggambarkan bahwa faktor harga memiliki pengaruh yang rendah terhadap bauran pemasaran pada PT. Global Imoo Telekomunikasi Bengkulu karena harga yang ditawarkan oleh watch phone Imoo tergolong harga yang lumayan tinggi karena pada saat ini banyak bermuncunlan jam tangan 
pintar Imoo dengan merek lain yang dijual dengan harga yang jauh lebih murah.

\section{Simpulan}

1. Nilai rata-rata dari tanggapan responden terhadap bauran pemasaran pada PT. Global Imoo Telekomunikasi Bengkulu adalah sebesar 1.003 dengan kriteria penilaian setuju. Artinya responden memiliki penilaian setuju terhadap bauran pemasaran pada PT. Global Imoo Telekomunikasi Bengkulu dipengaruhi oleh faktor produk, harga, promosi dan distribusi.

2. Faktor yang tertinggi mempengaruhi bauran pemasaran pada PT. Global Imoo Telekomunikasi Bengkulu adalah faktor produk dengan skor sebesar 1.067. Hal ini menggambarkan bahwa kualitas produk jam tangan pintar Imoo yang dijual oleh PT. Global Imoo Telekomunikasi memiliki kualitas yang bagus, selain bisa digunakan untuk berkomunikasi, jam tangan pintar Imoo juga dapat digunakan untuk memantau keberadaan anak.

3. Faktor terendah adalah pada faktor harga dengan total skor sebesar 964 dengan kriteria penilaian setuju. Hal ini menggambarkan bahwa faktor harga memiliki pengaruh yang rendah terhadap bauran pemasaran pada PT. Global Imoo Telekomunikasi Bengkulu karena harga yang ditawarkan oleh watch phone Imoo tergolong harga yang lumayan tinggi karena pada saat ini banyak bermuncunlan jam tangan pintar Imoo dengan merek lain yang dijual dengan harga yang jauh lebih murah.

\section{Saran}

1. Diharapkan kepada PT. Global Imoo Telekomunikasi Bengkulu untuk mempertimbangkan harga dari jam tangan pintar Imoo karena banyaknya muncul produk sama dengan harga yang jauh lebih murah.

2. Diharapkan kepada PT. Global Imoo Telekomunikasi Bengkulu untuk meningkatkan promosinya agar masyarakat lebih mengenal dan memahami kelebihan dari jam tangan pintar Imoo.

\section{DAFTAR PUSTAKA}

Alma, Buchari, 2016, Manajemen Pemasaran Dan Pemasaran Jasa, cetakan kelima, edisi revisi, Penerbit : Alfabeta, Bandung.

Assauri, Sofyan, 2017, Manajemen Pemasaran : Dasar, Konsep dan Strategi, Cetakan kedelapan, Penerbit ; PT. Raja Grafindo, Jakarta.

Fuad, 2015. Pengantar Bisnis, edisi keenam, cetakan ketigabelas, Penerbit : Gramedia Pustaka Utama, Jakarta

Gitosudarmo, Indriyo, 2014, Manajemen Pemasaran, edisi pertama, cetakan keempat, Penerbit : BPFE Yogyakarta

Hurriyati, Ratih, 2015, Bauran Pemasaran dan Loyalitas Konsumen, cetakan pertama, Penerbit : Alfabeta, Bandung

Kotler Philip, 2016, Manajemen Pemasaran, edisi Millenium, terjemahan Hendra Teguh, dan Ronny A. Rusli, Penerbit : Prenhallindo, Jakarta

Miles, B. Mathew dan Michael Huberman. 2014. Analisis Data Kualitatif Buku Sumber Tentang Metodemetode Baru. Jakarta: UIP.

Sihalolo, Ronny Ontama, 2013, Analisis Pemasaran Kentang Dan Kubis Untuk Tujuan Ekspor Pada Tingkat Gabungan Kelompok Tani (Gapoktan) Kabupaten Karo, Skripsi, Universitas Sumatarera Utara

Sugiyono, 2013. Metode Penelitian Kuantitatif dan Kualitatiif dan R\&D. Bandung: Alfabeta

Sunarto, 2015, Prinsip-Prinsip Pemasaran, Penerbit : AMUS, Yogyakarta

Swastha, Basu , 2014. Manajemen Pemasaran Modern; Yogyakarta: BPFE

Swastha, Basu, dan Handoko, T. Hani, 2014, Manajemen Pemasaran, Analisa Perilaku Konsumen, edisi pertama, cetakan keempat, Penerbit : BPFE, Yogyakarta

Yazid, 2014, Pemasaran Jasa Konsep dan Implementasi, edisi kedua, cetakan ketiga, Ekonisia, Yogyakarta 